\title{
Lateral Torsional Buckling of an Eccentrically Loaded Channel Section Beam
}

\section{Dahmani ${ }^{1}$ and S. Drizi}

Mouloud Mammeri University, Tizi-Ouzou, Algeria

${ }^{1}$ Lahlou_d@yahoo.fr

УДК 539.4

\section{Торсионная поперечная потеря устойчивости профилей металлопроката при нагрузке с эксцентриситетом}

\author{
Л. Дахмани, С. Дризи \\ Университет им. Мулуда Маммери, Тизи-Узу, Алжир
}

Профили металлопроката находят широкое практическое применение в качестве балок. Однако в стандарте Еврокод 3 отсутствуют рекомендации по расчету балок из профилей металлопроката в условиях нагружения с эксиентриситетом, т.е. смещения линии нагружения относительно центра сдвига. Выполнен расчет критических нагрузок для профилей металлопроката в условиях изгиба с эксиентриситетом, а его результаты сравниваются с данными, полученными методом конечных элементов на основании параметрического подхода. Предложен новый метод расчета, хорошо согласующийся с положениями стандарта Еврокод 3.

Ключевые слова: программа ANSYS, метод конечных элементов, торсионная поперечная потеря устойчивости, профиль металлопроката.

Introduction. Steel channel sections are often used in the building practice. The structural behavior of mono-symmetric channel sections is different from that of double-symmetric cross sections such as solid or I shaped cross section as shown in Fig. 1. This difference exists because the shear center $(S)$ and center of gravity $(C)$ do not coincide. If the applied load goes through the shear center of a channel section (Fig. 1d), the load is called "centric." It has been shown that [1-4] standard code requirements for lateral torsional buckling of double symmetric cross sections can be used for the design of centrically loaded channel sections.

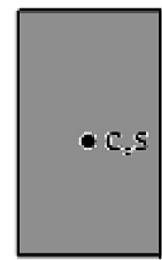

a

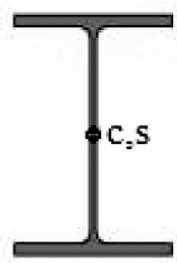

$\mathrm{b}$

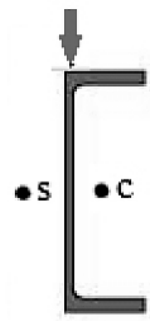

$\mathrm{C}$

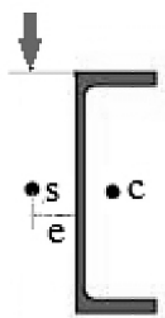

d

Fig. 1. Cross section: (a) solid, (b) double symmetric, (c) eccentrically loaded, and (d) centrically loaded. 
Theoretical Background. In practice, channel sections are most frequently eccentrically loaded (Fig. 2). However, no specific design rules are available in Eurocode 3 $[5,6]$ for lateral torsional buckling of eccentrically loaded channel sections used as beam. On the basis of parameter study, a new design rule is proposed in literature [7,8], which is in line with the design rule in Eurocode 3.

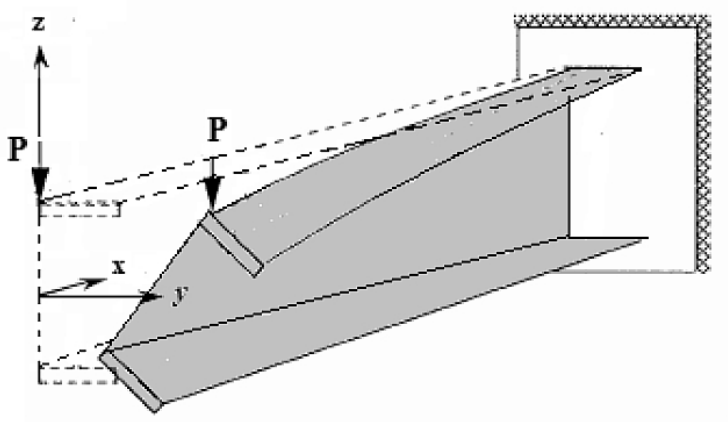

Fig. 2. Lateral torsional buckling of a cantilever channel beam.

Modified $\chi_{L T}$ Method. For channel sections, the relative slenderness $\bar{\lambda}_{L T}$ must first be adjusted to account for torsion. This has been achieved by adding a term $\bar{\lambda}_{T}$. The modified relative slenderness $\bar{\lambda}_{M T}$ to account for the eccentrically loaded channel sections is as follows:

$$
\bar{\lambda}_{M T}=\bar{\lambda}_{L T}+\bar{\lambda}_{T}
$$

The torsion term $\bar{\lambda}_{T}$ depends on the relative slenderness as follows:

$$
\bar{\lambda}_{T}=\left\{\begin{array}{lll}
1.1-\bar{\lambda}_{L T} & \text { if } & 0.5 \leq \bar{\lambda}_{L T}<0.75 \\
0.69-0.44 \bar{\lambda}_{L T} & \text { if } & 0.75 \leq \bar{\lambda}_{L T}<1.14 \\
0.19 & \text { if } & \bar{\lambda}_{L T} \geq 1.14
\end{array}\right.
$$

The adjusted reduction factor is given by

$$
\chi_{L T}=\frac{1}{\varphi_{L T}+\left[\varphi_{L T}^{2}-\bar{\lambda}_{M T}^{2}\right]^{0.5}}
$$

with

$$
\varphi_{L T}=0.5\left[1+\alpha_{L T}\left(\bar{\lambda}_{M T}-0.2\right)+\bar{\lambda}_{M T}^{2}\right]
$$

where $\bar{\lambda}_{M T}$ is the modified relative slenderness according to (1) and $\alpha_{L T}$ is the imperfection factor corresponding to the relevant buckling curve.

$$
M_{b, R d}=\chi_{L T} W_{p l, y} / \gamma_{M 1}=\chi_{L T} M_{p l y, R d} .
$$

The design rule became

$$
M_{S d} \leq M_{b, R d}=\chi_{L T} M_{p l y, R d},
$$


where $M_{S d}$ is the design bending moment due to the applied loading and $M_{p l y, R d}$ is the plastic moment capacity of the cross section along $y$ axis.

In this way the effect of torsion is included in the Eurocode 3 design rules. This will be called the modified $\chi_{L T}$ method.

Finite Element Method. A commercial finite element software ANSYS [9], was used for the analysis. An eigenvalue analysis was used to get the deflected shape (mode shape or eigenvector) and the associated load factor (eigenvalue). The resulting eigenvalues are actually the load factors to be multiplied by the applied loading $\left(1 \mathrm{kN} / \mathrm{m}^{2}\right)$, in order to obtain the critical buckling load. The element used in ANSYS [9], BEAM 188, is a quadratic three-dimensional beam element suitable for analyzing slender to moderately stocky beams. It possesses warping degrees of freedom, in addition to the conventional six degrees of freedom (Fig. 1). The numerical results of the buckling analysis are shown in Fig. 3, where the buckled shape and the load factor are indicated. (Fig. 3) depicts the behavior of the lateral torsional buckling, where lateral displacement combined with twisting can be observed.

Validation. In order to validate the finite element model developed for this investigation, an eigenvalue buckling analysis was carried out for the models shown in Fig. 3, and the predicted load factors (Table 1) were compared with the theoretical values of the lateral torsional buckling capacity. The difference between the results calculated using formula is $\Delta=\frac{\left|\mu_{\text {ANSYS }}-\mu_{\text {theor }}\right|}{\mu_{\text {ANSYS }}}$.

$\mathrm{T}$ a b 1 e 1

\section{Predicted Load Factors}

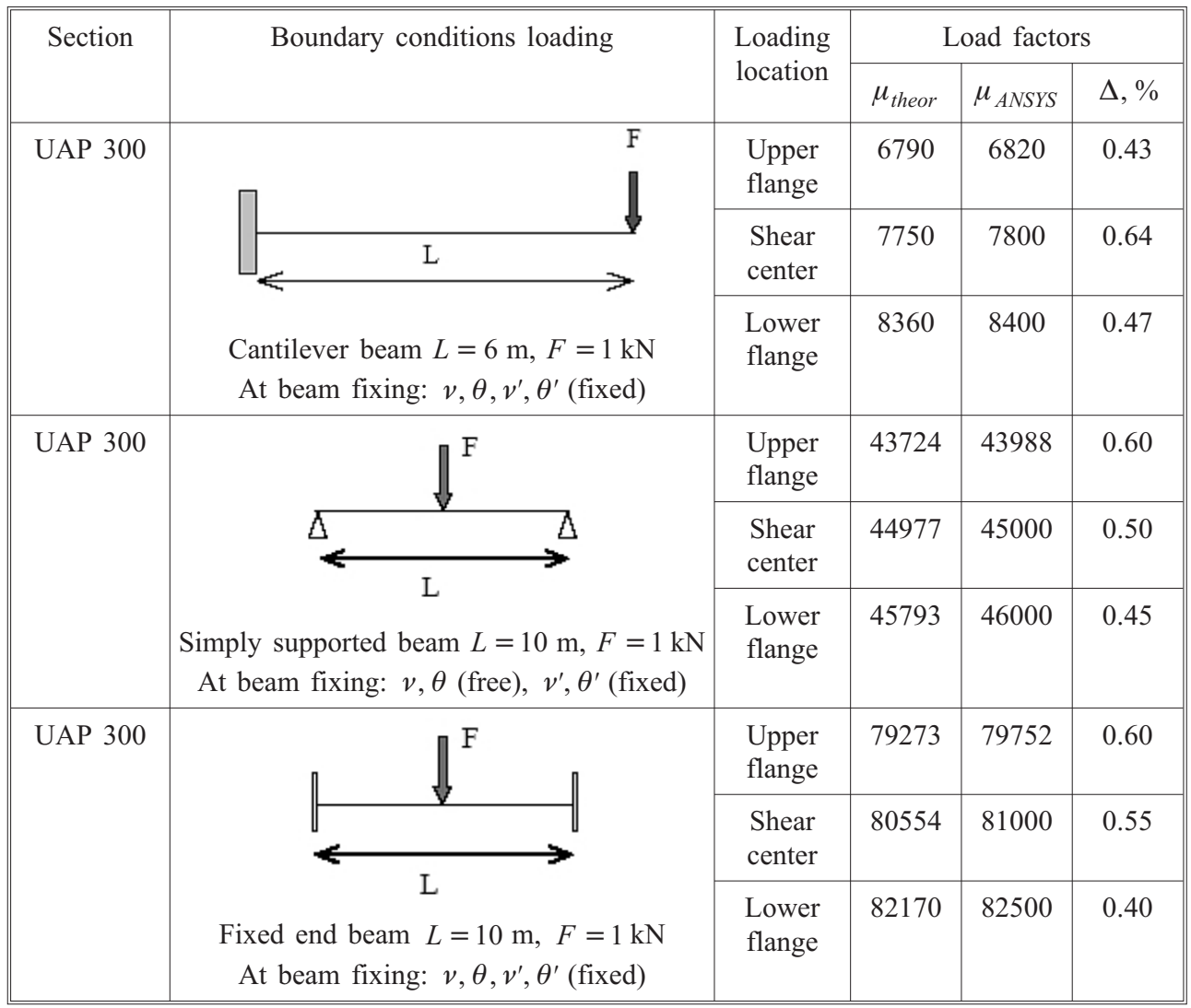


Lateral Torsional Buckling of an Eccentrically Loaded ...

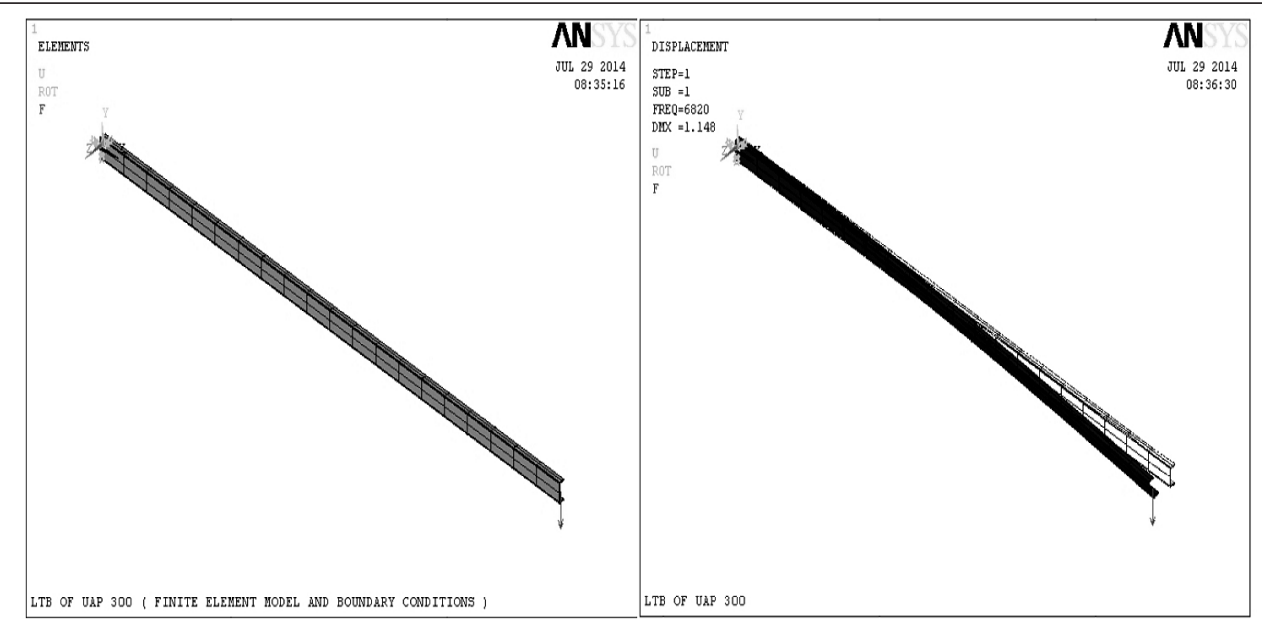

a
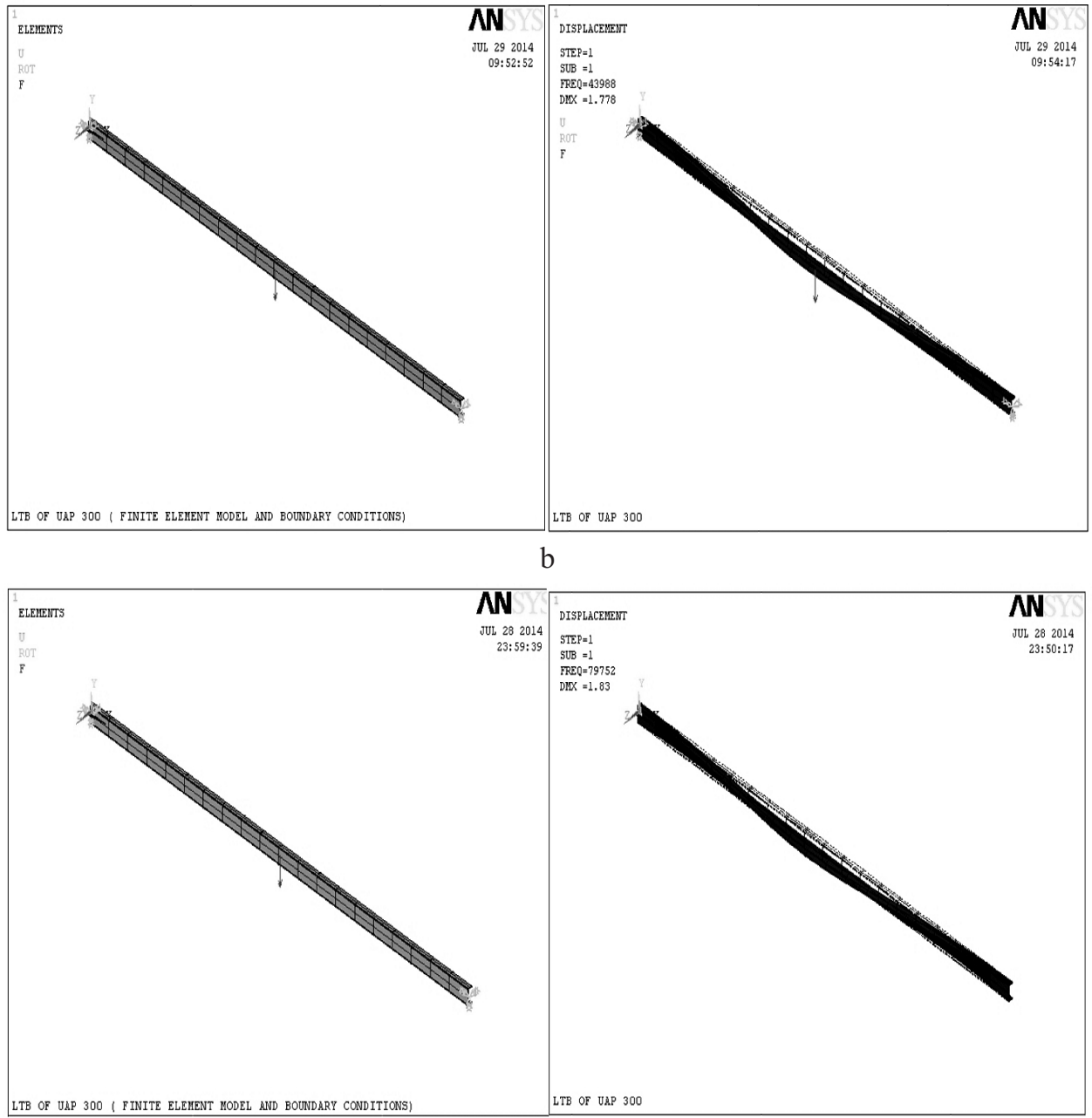

Fig. 3. Numerical buckling analysis results: (a) cantilever channel beam; (b) simply supported channel beam; (c) fixed end channel beam. 
The buckling capacity predicted using the beam element BEAM 188 from ANSYS [9] is within $0.6 \%$ of the theoretical value.

The above figures show the behavior of the lateral torsional buckling; we can observe the lateral displacement in combination with twisting.

Conclusions. This paper compares ultimate lateral torsional buckling loads of unrestrained channel beams in bending based on adjusted design rules to ultimate loads obtained with finite element simulations. It can be concluded that the adjusted design method can lead to the underestimations of even less than $0.5 \%$ of the ultimate lateral torsional buckling load of unrestrained beams obtained from finite element simulations. The new design method gives good results for lateral torsional buckling of steel channel beams loaded eccentrically without restraints between the supports.

\section{Резюме}

Профілі металопрокату знаходять широке практичне застосування як балки. Проте у стандарті Сврокод 3 відсутні рекомендації щодо розрахунку балок з профілів металопрокату в умовах навантаження 3 ексцентриситетом, тобто зміщення лінії навантаження відносно центра зсуву. Виконано розрахунок критичних навантажень для профілів металопрокату в умовах їхньго згину з ексцентриситетом, а його результати порівнюються 3 даними, отриманими методом скінченних елементів на основі параметричного підходу. Запропоновано новий метод розрахунку, який добре узгоджується $з$ положеннями стандарту Єврокод 3.

1. N. Boissonnade, R. Greiner, J. P. Jaspart, and J. Lindner, Rules for Member Stability in EN1993-1-1 - Background Documentation and Design Guidelines, ECCS TC8 Stability, ECCS Report No. 119, ISBN 92-9147-000-84, ECCS, Brussels, Belgium (2007).

2. C. H. M. de Louw, Design Rule for Lateral Torsional Buckling of Channel Section, MSc Thesis Nr. 0-2007.21, Department of Architecture Building and Planing, Eindhoven University of Technology, the Netherlands (2007).

3. H. H. Snijder, F. S. K. Bijlaard, and H. M. G. M. Steenbergen, "FEM simulations of lateral torsional buckling experiments on channel sections loaded in bending," in: A. Lamas and L. S. da Silva (Eds.), Proceedings of the 3rd European Conference on Steel Structures (Sept. 19-20, 2002, Coimbra, Portugal), CMM, Coimbra, Portugal (2002), pp. 201-210.

4. D. B. la Poutré, H. H. Snijder, and J. C. D. Hoenderkamp, "Lateral torsional buckling of steel channel shaped beams experimental research," in: Proc. of the Third Int. Conf. on Coupled Instabilities in Metal Structures, Lisbon, Portugal (2000), pp. 265-272.

5. EN 1993-1-1. Eurocode 3: Design of Steel Structure - Part 1-1: General Rules and Rules for Building (2006).

6. H. H. Snijder and J. C. D. Hoenderkamp, "Buckling curves for lateral torsional buckling of unrestrained beams," in: Proc. of the Homages a Rene Maquoi Birthday Anniversary, Universite de Liege, Belgium (2007), pp. 239-248.

7. N. S. Trahair, "Multiple design curves for beam lateral buckling," in: T. Usami and Y. Itoh (Eds.), Stability and Ductility of Steel Structures, Pergamon (1998), pp. 1326. 
8. N. S. Trahair, Flexural-Torsional Buckling of Structures, CRC Press, Boca Raton (1993).

9. ANSYS 13.0. The General Purpose of Finite Element Software. Documentation.

Received 08. 05. 2015

\section{Вниманию подписчиков!}

Подписаться на журнал «Проблемы прочности» можно, как обычно, в местных отделениях связи. Журнал включен в каталоги Украины и России.

Наш индекс - 70730.

Подписку Вы можете оформить непосредственно в редакции журнала с любого очередного номера.

Цена одного номера с учетом почтовых расходов в 2016 году составит:

в пределах Украины 60 грн.;

за пределами Украины 10.0 USD.

Почтовые переводы направлять по адресу:

01014, Киев-14, ул. Тимирязевская, 2.

Редакция журнала «Проблемы прочности»

Шинкаренко Нине Михайловне.

Справки по телефону: (044) 2865657.

Отдельным письмом необходимо сообщить в редакцию требуемое количество номеров, сумму и дату отправки перевода, указать свой почтовый адрес. Отправка журналов осуществляется после поступления денег подписчика. 